\title{
4 Mere compliance or learning - M\&E culture in the public service of Benin, Uganda and South Africa
}

\author{
Ian Goldman, Wole Olaleye, Stanley Sixolile \\ Ntakumba, Mokgoropo Makgaba and Cara Waller
}

\section{Summary}

This chapter builds on research on the performance monitoring and evaluation (M\&E)culture in Benin, Uganda and South Africa conducted through the Twende Mbele African M\&E partnership, which is presented here to provide a context for the cases in the book. The research was conducted on approximately five national departments per country and 368 managers were interviewed: 149 from Benin, 127 from South Africa, and 92 from Uganda. We see a mixed picture and many similarities in the three countries. Overall, all three have significant planning and monitoring systems and an established evaluation system. Around half of managers are seen to be using evidence from M\&E, with evaluations used particularly in an ex-post role rather than during the life of interventions. The effect of each country's national evaluation system is recognised. However, there is also evidence of negative behaviour, using reports to conceal information, not interrogating the cause of failure. The survey is itself a baseline for Twende Mbele and the trends in these figures will be interesting.

\section{Introduction}

\section{Background}

Many countries in Africa are using M\&E as part of their efforts to improve performance of the public sector (Porter and Goldman, 2013). Three pioneer countries in establishing government-led national evaluation systems (NES) are Uganda, Benin and South Africa (SA), which have been working together since 2012 to share experience around M\&E. Since 2016, this has been formalised through the Twende Mbele African government $+\mathrm{M} \& \mathrm{E}$ partnership. One of Twende Mbele's projects was a survey of the state of performance M\&E culture in national departments in the three countries. This chapter draws on this research and other literature to critically analyse the context for using evidence in African governments, building on the analytical framework guiding this book in Chapter 3, particularly the component on context drawn from Politics and Ideas (Weyrauch et al., n.d.).

Prior to this study there was little systematic empirical information on M\&E culture within the public sector in Africa. Despite evidence suggesting that 
$\mathrm{M} \& \mathrm{E}$ is gaining political recognition in the public sector, its ability to influence the efficacy of policies, projects, programmes and interventions remains unclear.

The purpose of the research was to assess the state of performance M\&E culture in the three participating governments by seeing how each country's various $M \& E$ systems interact to improve performance and accountability, with a specific focus on policy, approach, concepts, framework and organisational arrangements in the public sector. ${ }^{1}$ Initial interviews were conducted with 14 managers and used to help design the survey. A representative probability sample size of 490 senior managers was selected from across 22 national departments and ministries. In total, 368 managers were interviewed: 149 from Benin, 127 from South Africa, and 92 from Uganda. A survey instrument was administered either in a face-toface interview or the questions were answered in writing and submitted electronically. The interviews were conducted using in-country researchers in either French or English. Quantitative responses were analysed using Stata.

This chapter also draws on wider literature from the three countries and highlights some of the barriers and facilitators to a performance culture.

\section{What is a MEE culture that promotes performance?}

Culture conveys a sense of identity to employees, provides unwritten and, often, unspoken guidelines on how to get along in an organisation. ... An organisational culture is reflected by what is valued, the dominant leadership styles, symbols, the procedures, routines, and the definition of success that make an organisation unique.

(Cameron and Quinn, 1999, pp. 2-3)

The cultures of monitoring and evaluation are distinct. Monitoring involves tracking what has been planned, while evaluation is a systematic and rigorous analysis of interventions to assess and strengthen their performance. A monitoring culture is often closely linked to compliance with reporting requirements, while evaluation is usually more linked to a learning culture (Goldman et al., 2018). Mayne (2010,p. 6) describes an organisation with an evaluative culture as one that:

deliberately seeks out empirical information to learn how to better manage its programs and services, and thereby improve its performance.... [It] is this evidence-seeking behaviour that characterises an evaluative culture and distinguishes it from a more general learning culture.

M\&E culture is composed of perception, underlying assumptions, beliefs and values, reflected in the degree of support by senior management, people's behaviour and institutional practices, and embedded in policies, guidelines, tools and procedures (Mayne, 2010). For an organisation to establish a culture that goes beyond monitoring to promote the use of $M \& E$ evidence, it must have a system in place to use what may be critical evaluative information for learning and improvement. An organisation with a strong evaluative culture is likely to use empirical information to influence policy making and implementation.

In this chapter we define M\&E culture as a 'shared set of ideas, values, beliefs and practices at an organisational level about M\&E's role, functions and practice, 
and use of the knowledge generated for managing, reporting, learning and accountability and to improve performance'.

\section{How organisational context contributes to $M E E$ use - an emerging analytical framework}

There are few empirical studies on M\&E culture in Africa published in peerreviewed journals. Much of the information is in the form of grey literature, which is difficult to access, hence the importance of this research undertaken in Benin, Uganda and South Africa. We also draw from other sources including research in South Africa (Paine et al., 2015, Umlaw and Chitepo, 2015), Ethiopia (Rogger and Somani, 2018) and Nigeria (Uneke et al., 2011).

The analytical framework for the book, presented in Chapter 3, identifies the following elements around the organisational context: macro-context, organisational capacity, management and processes, culture, intra- and interinstitutional linkages and other resources. The first two elements are external, and the remaining four are internal to the organisation.

The survey did not cover many questions in relation to the first two dimensions, macro-context and inter-institutional relationships, and so we primarily use other sources for this information.

We discuss the findings in relation to the elements of this framework, indicate the enabling and hindering factors identified in the research and from other sources, and conclude.

\section{Findings}

\section{Macro-context}

Weyrauch et al. (2016) see the macro-context as the over-arching forces that establish the 'bigger picture' in which policy is made, including political, economic, social and cultural systems, and, consequently, how research can or cannot inform it.

Development of the M\&E systems in each country is discussed by the three country champions in Goldman et al. (2018). Political will was a factor in the development of all three national M\&E systems, for example, in South Africa in 2010 (Phillips et al., 2014). In all three cases a structure for championing M\&E was established either in the Presidency or Office of the Prime Minister (OPM), thus making it easier to oversee sectoral ministries (see Table 4.1). This provided high level leadership/champions, both at a technical (head of department) and a political (minister) level, championing M\&E systems within their respective organisations and governments. This was mentioned by interview respondents as an important strength (Table 4.6).

Particular transitions and events have provided pressure for change and to establish M\&E systems, as well as to undermine them. In Benin and South Africa, leadership changes have meant that the strength of national champions has varied, while there has been stronger continuity in Uganda. In Benin this has been due particularly to changes in the presidency and shifts of the location 
Table 4.1 The situation with regard to evaluation/M\&E units in each country

\begin{tabular}{|c|c|c|c|}
\hline Components & South Africa & Benin & Uganda \\
\hline $\begin{array}{r}\text { Institutional } \\
\text { champion }\end{array}$ & $\begin{array}{l}\text { DPME in the } \\
\text { presidency }\end{array}$ & $\begin{array}{l}\text { Office for Evaluation } \\
\text { of Public Policies } \\
\text { and Actions, Benin } \\
\text { (BEPPAG) in } \\
\text { presidency }\end{array}$ & $\begin{array}{l}\text { Department of M\&E } \\
\text { with Government } \\
\text { Evaluation Facility in } \\
\text { OPM }\end{array}$ \\
\hline $\begin{array}{l}\text { Evaluation and/ } \\
\text { or M\&E units in } \\
\text { line ministries }\end{array}$ & $\begin{array}{l}\text { All national and } \\
\text { provincial } \\
\text { departments have } \\
\text { M\&E units. Sector } \\
\text { M\&E units link } \\
\text { vertically }\end{array}$ & $\begin{array}{l}\text { All line ministries } \\
\text { have their own } \\
\text { M\&E system } \\
\text { that links to } \\
\text { the Ministry of } \\
\text { Planning }\end{array}$ & $\begin{array}{l}\text { M\&E policy } \\
\text { recommended } \\
\text { creation of M\&E } \\
\text { units. Office of } \\
\text { Prime Minister } \\
\text { (OPM) is working } \\
\text { with Ministry of } \\
\text { Public Service to } \\
\text { establish M\&E units }\end{array}$ \\
\hline $\begin{array}{l}\text { Evaluation and/ } \\
\text { or M\&E units } \\
\text { at decentralised } \\
\text { levels }\end{array}$ & $\begin{array}{l}\text { All provinces have } \\
\text { M\&E units, } \\
\text { but connection } \\
\text { between national } \\
\text { and provincial } \\
\text { M\&E is not } \\
\text { systematic, except } \\
\text { within some } \\
\text { sectors. }\end{array}$ & $\begin{array}{l}\text { All municipalities } \\
\text { have M\&E units, } \\
\text { but these are not } \\
\text { connected to } \\
\text { national ones }\end{array}$ & $\begin{array}{l}\text { M\&E function is } \\
\text { performed under } \\
\text { district planning } \\
\text { units. Efforts } \\
\text { underway to have } \\
\text { specific evaluation } \\
\text { staff }\end{array}$ \\
\hline
\end{tabular}

Source: Goldman et al. (2018), p. 8.

between a ministry and presidency, while in South Africa it is changes in leadership of the M\&E champion. These changes also play out at the sectoral level and can have major impacts on performance.

I was doing M\&E of local government in 2008/09 and another Minister came and he dismantled the M\&E branch which was responsible for overseeing the work of the sector country-wide ... he did not understand their role and saw them as people who are there to merely write up reports.... That led to a collapse of a very strong M\&E system which has not been yet been revived.

(SA respondent 5)

None of the countries yet has legislation for overarching M\&E, although Benin and South Africa have been drafting legislation. All three have policies for M\&E (Uganda) or evaluation (Benin and South Africa), and sector laws often include $\mathrm{M} \& \mathrm{E}$ roles.

Besides leading the M\&E function, if a government-wide M\&E system is desired it must be mainstreamed within the public sector through transversal policies, systems and coordination mechanisms. All national departments in Benin and South Africa have M\&E units, and these are being established in Uganda, as shown in Table 4.1. However, in all three countries, around $50 \%$ of respondents said these units had 
little influence (Table 4.3). Some respondents indicated that M\&E units had most influence when they were located in the office of the head of department/ministry, as in the South African Department of Trade and Industry.

\section{Intra- and inter-institutional linkages}

According to Weyrauch et al. (2016, p. 35),

Two particular types of relationship exert significant influence over how knowledge interacts (or not) with policy. One is related to internal relationships between the government institution and other related government agencies. The second one relates to interaction with relevant users and producers of knowledge who can affect or be affected by policy design and implementation.

Factors that influence evidence use include formal channels of interaction between policy makers and researchers, policy forums, and involvement of civil society in policy processes. Some of these relationships can be seen in the level of the degree of coordination within government, the degree of communication between stakeholders, and then the degree to which performance information is used by wider stakeholders for accountability of government. We explore these in turn in the following subsections.

\section{Coordination}

Coordination is seen to be necessary when 'an outcome can only be improved or attained through coordinated government action, and when the benefits ... outweigh the costs... . But coordination takes time, resources and energy, so it needs to be carefully planned and focused to be effective' (New Zealand State Services Commission, 2008 quoted in DPME (2014, p. 13).

Government departments working in silos appear to be universal. One of the reasons for the gap between government's stated intentions and the reality of government services experienced by citizens is poor coordination (Gregory, 2006). An evaluation of the interdepartmental cluster system in South Africa concluded that

the structures are not optimally meeting their roles and mandates... only $50 \%$ (of respondents) felt that the quality of decisions was good, and only $32 \%$ that there was good accountability for implementing cluster decisions.... On average only $6 \%$ of clusters' time was spent unblocking implementation, while $32 \%$ was spent on reporting.

(DPME, 2014)

Cultural issues including leadership, skills and incentive systems are key to achieving coordination.

All three countries have created coordination structures to support evaluation systems: in Benin the National Council for Evaluation, in Uganda the 
National Evaluation Board, and in South Africa an M\&E Forum and National Evaluation Technical Working Group. These provide oversight and support the system, and they are involved in selection of priority evaluations (Goldman et al., 2018). However, coordination is difficult.

In the three countries there are also different organisations with roles related to $M \& E$, and reporting to these organisations was found to cause confusion and fatigue. Duplicate reporting requirements strengthen malicious compliance, as energy is directed to compliance reporting and not for learning and continuous improvement.

In Uganda and Benin there are much higher levels of involvement of civil society in M\&E systems, with civil society and donors represented on M\&E coordination structures, whereas in South Africa involvement of civil society is weak (DPME, 2018).

\section{Communication with stakeholders}

The Mo Ibrahim index (2018) on access to public information shows South Africa scoring high, Uganda midway, and Benin very low and falling. In the research, around $60 \%$ of respondents replied that evaluation reports were shared with only $45 \%-53 \%$ of respondents, indicating that websites were used to share evaluation reports. There are attempts to make available performance information, for example all three countries have a public repository for evaluation reports. ${ }^{2}$ There is a much lower use of other communication mechanisms with the public.

In general, the resources involved in communicating with the public and wider stakeholders are limited. One of the recommendations in the evaluation of South Africa's national evaluation system (NES) was

to allocate significant resources for evaluation communication, both financial and human. This will ensure full value is obtained from the investment currently being made, and that stakeholders are aware of the findings. This will also help to build trust in government.

(DPME, 2018, p. xii)

Stakeholders use performance information to hold government accountable

All three countries have systems for wider accountability of government to stakeholders. In the Mo Ibrahim index, South Africa scores highly in Africa in access to records, accountability and sanctions for abuse of office. Benin and Uganda are in the middle of African countries (Mo Ibrahim Foundation) ${ }^{3}$. Uganda publishes an Annual Performance Report for government and a Local Government Performance Assessment. ${ }^{4}$ In South Africa, departments produce annual reports that are on departments' websites, but these are produced for compliance purposes and to report to Parliament rather than communicating with wider stakeholders. Parliamentary committees 'scrutinised all our performance reports on a quarterly (basis) and there are even follow-ups on whether evaluation recommendations have been implemented and that must be done in writing through the presentation' (SA respondent 1). In Uganda and Benin, the 
reliance on donors for programme support and evaluations has benefits in terms of creating demand for performance information that is used for accountability but presents risks in terms of creating parallel reporting systems to both donor agencies and central bodies such as the OPM.

\section{Culture}

In all three countries, respondents felt that learning is documented and used to improve results and changes are implemented for that purpose (around $71 \%$ of managers) (Table 4.2). One of the challenges is how organisations respond to negative findings. Respondents from all three countries indicated that negative findings are reflected on, learning is documented and used to improve future results, and changes are implemented. Only in around $25 \%-30 \%$ of cases do managers reject the findings and are reluctant to change (Table 4.2).

Some civil servants look at the $M \& E$ function as a punitive function. Thus $62.7 \%$ of respondents in Uganda said that responsible officials are sanctioned for poor performance - much higher than in Benin or South Africa (Table 4.2). Around half of the managers suggested that stringent bureaucratic hierarchies make it difficult to openly discuss performance, managers fearing admitting mistakes and managers never/rarely championing M\&E (Table 4.3). These tend to indicate more closed organisational cultures. Of concern is that Benin indicates that $26.9 \%$ of the respondents say that results are ignored.

The fear of making mistakes can be seen in that half of managers said, 'problems are never/rarely treated as an opportunity for learning and improvement'.

If there is a budget cut, you will find that some entities will first think about cutting M\&E because [they] don't appreciate the importance of M\&E in their work. There are some civil servants who look at M\&E function as witch-hunting and they would not like to be associated with such a function.

(Uganda respondent 3)

Table 4.2 Perceived responses when the ministry/department's performance is below expectation

\begin{tabular}{|c|c|c|c|}
\hline \multirow[t]{2}{*}{ How likely are the following: } & \multicolumn{3}{|c|}{$\%$ of respondents saying always/often } \\
\hline & $S A$ & Benin & Uganda \\
\hline Results are ignored & 10.6 & 26.9 & 8.0 \\
\hline $\begin{array}{l}\text { Managers tend to reject the accuracy of } \\
\text { results that are poor }\end{array}$ & 23.1 & 24.9 & 22.7 \\
\hline Responsible official is sanctioned & 33.7 & 28.9 & 62.7 \\
\hline $\begin{array}{l}\text { Responsible official is required to explain } \\
\text { and identify how results can be improved }\end{array}$ & 72.1 & 69.8 & 80.0 \\
\hline $\begin{array}{l}\text { Learning is documented and used to } \\
\text { improve future results }\end{array}$ & 69.3 & 72.5 & 70.7 \\
\hline Changes are implemented to improve results & 71.2 & 69.8 & 74.7 \\
\hline
\end{tabular}


Table 4.3 Values and culture barriers to effective use of evaluation in decision making, learning and accountability in your department

\begin{tabular}{llll}
\hline Are any of the following a barrier? & \multicolumn{2}{l}{ \% of respondents saying always /often } \\
\cline { 2 - 4 } & SA & Benin & Uganda \\
\hline $\begin{array}{l}\text { No consistent demand for evaluation from } \\
\text { ministers and management }\end{array}$ & 23.1 & 28.2 & 32.0 \\
$\begin{array}{l}\text { Time pressure means decisions are often } \\
\text { taken without proper diagnosis of the } \\
\text { problem }\end{array}$ & 42.3 & 44.3 & 41.3 \\
$\begin{array}{l}\text { Resistance from senior management to } \\
\text { transparent decision-making processes }\end{array}$ & 27.9 & 35.6 & 33.3 \\
$\begin{array}{l}\text { Senior management do not champion } \\
\quad \text { M\&E and honesty about performance }\end{array}$ & 41.4 & 40.3 & 34.7 \\
$\begin{array}{l}\text { Little respect for evidence-based decision } \\
\text { making in the department }\end{array}$ & 27.9 & 30.9 & 34.7 \\
$\begin{array}{l}\text { The hierarchy makes it difficult to openly } \\
\text { and robustly discuss performance }\end{array}$ & 38.5 & 40.3 & 42.7 \\
$\begin{array}{l}\text { Managers fear admitting mistakes or } \\
\text { problems }\end{array}$ & 54.8 & 49.0 & 46.7 \\
$\begin{array}{l}\text { Problems not treated as an opportunity for } \\
\text { learning and improvement }\end{array}$ & 40.4 & 45.0 & 46.7 \\
$\begin{array}{l}\text { M\&E is regarded as the job of the M\&E } \\
\text { unit, not of all managers }\end{array}$ & 54.8 & 63.8 & 54.7 \\
$\begin{array}{l}\text { M\&E unit has little influence in the } \\
\text { department }\end{array}$ & 51.9 & 45.6 & 48.0 \\
$\begin{array}{l}\text { M\&E is seen by management as policing } \\
\text { and a way of controlling staff }\end{array}$ & 44.2 & 43.0 & 37.3 \\
$\begin{array}{l}\text { The concealing of findings is a barrier to } \\
\text { effective use of M\&E }\end{array}$ & 31.7 & 24.2 & 34.7 \\
$\begin{array}{l}\text { Concerns from managers about 'unhelpful' } \\
\text { conclusions about policies' effectiveness }\end{array}$ & 52.9 & 42.3 & 50.7 \\
\hline
\end{tabular}

However, when performance was above expectations, $20 \%-30 \%$ of managers were perceived as taking personal credit for good performance rather than crediting the team.

Overall, the value of $\mathrm{M} \& \mathrm{E}$ to help improve organisational performance is recognised by around half of managers who are open to change, using evidence from evaluation, and using problems as opportunities for learning. However, the other half indicate stringent hierarchies, closed compliance cultures and lack of appreciation of learning from experience by management - a serious impediment to improvement.

In terms of respondent comments on strengths related to culture (Table 4.6), several respondents indicated that systems were in place and that governments were now able to provide evidence of performance. In terms of weaknesses it was suggested that in Benin, there is lack of ownership of evaluation at the national level and the M\&E culture is still not strong, and in Uganda, lack of ownership of the M\&E function, lack of feedback and slow decision making. 


\section{Organisational capacity}

Weyrauch et al. (2016, p. 23) define organisational capacity as 'the ability of an organisation to use its resources to perform ... to design and implement public policies. It includes human resources and the legal framework that determines how resources can or cannot be used'. In terms of this definition, both leadership and general human resource capabilities are deemed important alongside other aspects such as policy, legal capacity and internal communication mechanisms.

In 2018, CLEAR AA found that the central coordinating bodies for M\&E and planning in Uganda have strong capacity and serve to provide guidance and support to national and local government institutions, while internal organisational capacity for $\mathrm{M} \& \mathrm{E}$ within other ministries is deemed to be quite weak compared to the external demands of central agencies. The evaluation of the South African NES also indicated that DPME played a critical role (DPME, 2018).

$\mathrm{M} \& \mathrm{E}$ units are well staffed with a mean of 8.47 posts (SA with 11.6 posts, Benin 6.3 and Uganda 10.6). In general, $M \& E$ is seen as the role of the M\&E unit rather than of all managers $(58.8 \%$ of respondents in SA, 63.8\% in Benin and $54.7 \%$ in Uganda). This can mean M\&E gets sidelined to M\&E units. It is interesting that an outstanding ministry in Africa in terms of evaluation, the Western Cape Department of Agriculture in South Africa, deliberately did not set up an $M \& E$ unit but left $M \& E$ as a strategic function in the office of the head of department (Joyene Isaacs, head of department, personal communication). ${ }^{5}$

Some respondents indicated major concerns about the capacity of MEE units to do their jobs, for example to analyse and produce their own reports or to manage and undertake evaluations, with around 55\% of managers indicating the capacity to conduct evaluations is weak.

Some of the capabilities in government needed to use evidence effectively include analytical thinking, the ability to interpret evidence and knowledge of the problem (adequate diagnosis). A smaller proportion say that managers do not have the skills to understand and use evaluation recommendations (33\% in SA, $28 \%$ in Benin and 25\% in Uganda) and having the management skills to use evaluation results. In practice, officials tend to use informal sources and trusted experts as sources of information rather than research, evaluation or research synthesis (Paine Cronin and Sadan, 2015). This is partly a skills issue, partly lack of staff to conduct research and generate evidence in government and also lack of awareness of the evidence that may already be available. ${ }^{6}$

\section{Management and processes}

\section{Systems in place}

Many of the survey respondents indicated that M\&E systems are in place and are institutionalised and standardised (Table 4.6). Some of these are discussed in the following subsections. 


\section{Strategic planning}

All three countries have national development plans monitored by government, civil society and development partners, with a national agency responsible for the national development plan. However, around $50 \%$ of respondents indicated that diagnosis of problems to inform planning happens rarely or never, confirmed in training of senior public managers conducted in the three countries.

\section{Linking plans to individual performance}

Performance agreements are a key link between ministry plans and individual performance. Respondents were asked whether 'departmental performance expectations as recorded in strategic and annual plans are linked to individual performance agreements'. There was seen to be a strong linkage in Uganda $(72.0 \%)$ and South Africa (75.6\%), but much weaker in Benin (42.9\%). Only $10 \%$ said they did not know whether departmental performance objectives are linked to individual performance agreements.

\section{Monitoring implementation}

In all three countries departments/ministries have annual plans, with over $80 \%$ of respondents reporting that indicators are embedded in these plans and that reports reflect progress. All three countries undertake routine monitoring of performance. However, $45 \%-52 \%$ of respondents indicated the focus of $\mathrm{M} \& \mathrm{E}$ is on activities and outputs (what we do) rather than outcomes and impact (what we achieve), reinforcing a compliance approach rather than encouraging achievement of desired development results. Key sectors such as health and education generally have integrated M\&E systems that cover the sector from service point to national levels.

\section{Evaluation being undertaken}

All three countries have national evaluation systems, with basic systems and some process of evaluations related to national priorities. Goldman et al. (2018) report on the characteristics of the different systems. While all three countries are undertaking evaluations, only around half of respondents in all three countries indicated that evaluation was always/often undertaken as a systematic research process $(49.3 \%$ in Uganda, $47 \%$ in Benin, $41.4 \%$ in SA). Overall, respondents indicated that strengths around evaluation include implementation of the policy, systems in place and the ability to show evidence of government's performance. Weaknesses included capacity, budget and limited evidence of use of evaluation results (Table 4.6).

\section{Timely information provided to decision makers}

This question is answered indirectly in 'time pressure means decisions are often taken without proper diagnosis of the problem'. Around $41 \%-44 \%$ of 
respondents in all three countries indicated that this happens always or often. This suggests that there is a problem with key evidence being unavailable when needed to make decisions. 'The information gets to us but not on time and most times [it is] not clear. The information is not usually used to make decisions' (Benin respondent 2). There is a need to get more rapid information for decision making, and the Twende Mbele programme has an initiative to look at rapid evaluation to help address this.

\section{Evidence used to inform decision making}

The point of generating evidence is so that it is used to support policy making and implementation. On average, $61 \%$ of respondents felt that $\mathrm{M} \& \mathrm{E}$ evidence was always/often used (58.4\% in Benin, 63.5\% in SA and 64\% in Uganda).

A respondent from South Africa expressed the power of the use of evaluation:

We are one of the best countries in terms of business process outsourcing simply because we did an evaluation which made it easy to look at how we can improve on the design and implementation.

(SA respondent 6)

This reflects a highly performing department that was an early adopter of evaluation in South Africa. However, other respondents indicated the challenge. A Ugandan respondent from the Office of the Prime Minister said:

The challenge which (evaluation) shares with the government assessment process is the issue of limited use of the findings.... we are happy when we have at least $30 \%$ of the evaluation findings adopted.

(Uganda respondent 2)

In Table 4.4 we see levels of over $60 \%$ in instrumental, conceptual, symbolic and process use. Around $45 \%$ of managers indicated they saw evidence of improvement in management practices as a result of using M\&E evidence, either instrumental or process use.

Only rarely is evaluation evidence used through the entire programme cycle $(8 \%-15 \%$ of respondents); in the majority of cases, the evidence is used when evaluations are completed (Table 4.5). Nevertheless, as shown in Table 4.4, around $60 \%$ of respondents did feel they learnt something during the evaluation process, rather than simply from findings and recommendations.

One of the challenges for use is that $30 \%-40 \%$ of respondents felt there were inadequate mechanisms for ensuring use (e.g. improvement plans), and that $25 \%-33 \%$ of managers do not have the skills to understand and use evaluation recommendations. 
Table 4.4 How evaluation recommendations are used

\begin{tabular}{|c|c|c|c|}
\hline \multirow[t]{2}{*}{ How often are evaluation recommendations used to: } & \multicolumn{3}{|c|}{$\%$ of respondents saying always or often } \\
\hline & $S A$ & Benin & Uganda \\
\hline Make changes in the policies (instrumental use) & 63.5 & 62.4 & 61.3 \\
\hline $\begin{array}{l}\text { Improve understanding of the intervention } \\
\text { (process or conceptual use) }\end{array}$ & 64.4 & 67.1 & 72.0 \\
\hline $\begin{array}{l}\text { Give legitimacy to a course of action taken } \\
\text { (symbolic use) }\end{array}$ & 66.4 & 63.8 & 69.3 \\
\hline $\begin{array}{l}\text { Enhance value derived from stakeholders' } \\
\text { participation in the planning and } \\
\text { implementation of evaluation } \\
\text { (process use) }\end{array}$ & 58.7 & 65.1 & 61.3 \\
\hline
\end{tabular}

Table 4.5 Stage at which countries use evaluation evidence

\begin{tabular}{llcc}
\hline When do you use evaluation evidence? & \multicolumn{2}{l}{ \% of respondents saying always or often } \\
\cline { 2 - 4 } & SA & Benin & Uganda \\
\hline $\begin{array}{l}\text { Throughout planning, designing and } \\
\text { implementation of programmes and } \\
\text { projects }\end{array}$ & 15.5 & 12.2 & 8.0 \\
\begin{tabular}{l} 
Once evaluation is completed \\
\hline
\end{tabular} & 32.0 & 47.6 & 42.7 \\
\hline
\end{tabular}

MEE evidence used to inform planning and budget

Respondents in all three countries indicated there were links between $\mathrm{M} \& \mathrm{E}$, planning and the budget.

There are officers in the ministry in charge of M\&E system and they know about the results of the evaluation findings. They are also the ones that initiate the costing at the ministry level, and they prepare the budget of all ministries.

(Benin respondent 1)

In Uganda, respondents indicated that OPM ensures that the recommendations from government assessment reports the previous year are the starting point for every departmental plan. Each sector develops a budget framework paper and OPM wants to see that these have addressed the previous year's recommendation and the percentage of the recommendation from the year that is addressed. 
In South Africa, respondents indicated that annual and quarterly reports do inform plans. Several indicated the need to use evidence to justify budgets, for example:

these days when you go to National Treasury and you want money for a programme or policy they ask you ... what has informed your case?

(SA respondent 3)

However, DPME has only managed to use a simple system drawing from evaluation findings to inform the national budget process. ${ }^{7}$ The need to improve this linkage led Twende Mbele in 2018 to support an international literature review on the experience of linking $M \& E$ with planning and budget, seeking to find tools from this to inform this function in the Twende partner countries. Good examples proved difficult to find. ${ }^{8}$

\section{Other resources}

We did not collect data to corroborate whether adequate budgets exist within departments/ministries for evaluation. However, respondents reported that inadequate resources in terms of both people and finance hamper M\&E practice and use of evidence for policy and decision making (see Table 4.6).

\section{The enablers and hindering factors to M\&E use}

\section{Enablers}

Some of the enablers related to values and culture which emerged relate to political will and the demand for M\&E evidence. The decision to locate the M\&E champion in a strong central office was an example of political will. It gave these departments authority, and within departments the M\&E unit had most authority when located in the office of the head of department or ministry. Around $70 \%$ of respondents indicated there was demand for evidence from ministers and management and recognition of the importance of $\mathrm{M} \& \mathrm{E}$ and learning in around $50 \%$ of managers, so a base of potential champions to work with exists.

Other system-related enabling factors are that national systems are in place, so systems are institutionalised and standardised, which is important in systems mainly driven by compliance. When donors reinforce government $\mathrm{M} \& \mathrm{E}$ systems, as in Uganda, this is enabling (and disabling when not the case). In addition, $M \& E$ information being made public creates a valuable resource for wider society.

\section{Hindering factors}

There were a number of cultural barriers to M\&E (Table 4.3). Turnover in leadership caused some disruption, leading to a desire for creating new systems 
Table 4.6 Summary of strengths and weaknesses

\begin{tabular}{|c|c|c|c|}
\hline Country & Element & Strengths & Challenges \\
\hline \multirow[t]{6}{*}{ Benin } & Culture & $\begin{array}{l}\text { Political will with } \\
\text { introduction of } \\
\text { evaluation in a ministry }\end{array}$ & $\begin{array}{l}\text { Lack of ownership of evaluation at } \\
\text { national level, M\&E culture still } \\
\text { not strong }\end{array}$ \\
\hline & Systems & $\begin{array}{l}\text { Some systems in place and } \\
\text { institutionalised with } \\
\text { some uniformity, e.g. } \\
\text { National Evaluation } \\
\text { Policy with tools } \\
\text { to implement, e.g. } \\
\text { guideline }\end{array}$ & Lack of sectoral evaluation plans \\
\hline & HR & & $\begin{array}{l}\text { Turnover of staff and lack of } \\
\text { institutional memory } \\
\text { Inadequate capacity of stakeholders } \\
\text { in evaluation. Lack of strong } \\
\text { quality assessors }\end{array}$ \\
\hline & Finance & & Resources for evaluation \\
\hline & $\begin{array}{l}\text { Follow-up } \\
\text { and use }\end{array}$ & $\begin{array}{l}\text { Now able to provide } \\
\text { evidence of the work } \\
\text { we are doing. The other } \\
\text { area is the issue around } \\
\text { uniformity }\end{array}$ & $\begin{array}{l}\text { Some recommendations not } \\
\text { implementable, inadequate } \\
\text { system to develop and follow-up } \\
\text { recommendations }\end{array}$ \\
\hline & Timeliness & & Information gets to us late \\
\hline \multirow[t]{11}{*}{ Uganda } & Culture & & $\begin{array}{l}\text { Some civil servants look at } M \& E \text { as } \\
\text { witch-hunting }\end{array}$ \\
\hline & & & $\begin{array}{l}\text { Lack of feedback. Sharing of } \\
\text { information is not good }\end{array}$ \\
\hline & & & $\begin{array}{l}\text { Most stakeholders are not aware of } \\
\text { existing policies and procedures }\end{array}$ \\
\hline & & & $\begin{array}{l}\text { Coordination issues at all levels of } \\
\text { government (ministry/district) }\end{array}$ \\
\hline & & & $\begin{array}{l}\text { Slow decision-making process in } \\
\text { the system }\end{array}$ \\
\hline & System & $\begin{array}{l}\text { Implemented more than } \\
65 \% \text { of the national } \\
\text { M\&E policy }\end{array}$ & $\begin{array}{l}\text { (System) mostly geared towards } \\
\text { monitoring and not evaluation }\end{array}$ \\
\hline & & $\begin{array}{l}\text { Our department meets to } \\
\text { discuss reports that we } \\
\text { submit to OPM every } \\
\text { six months }\end{array}$ & $\begin{array}{l}\text { Poor systems in some places, e.g. } \\
\text { some local governments still use } \\
\text { paper systems }\end{array}$ \\
\hline & & Tools have been good & $\begin{array}{l}\text { Joint agreements but government } \\
\text { and donors still sometimes do } \\
\text { their own thing }\end{array}$ \\
\hline & $\mathrm{HR}$ & $\begin{array}{l}\text { Implemented a lot of } \\
\text { capacity development }\end{array}$ & $\begin{array}{l}\text { Skills gap - very few staff. Need } \\
\text { M\&E posts in each ministry and } \\
\text { local government }\end{array}$ \\
\hline & & & $\begin{array}{l}\text { Poor capacity and skills, with poor } \\
\text { quality trainers in M\&E }\end{array}$ \\
\hline & & & Low salary and motivation of staff \\
\hline
\end{tabular}


68 Ian Goldman et al.

Table 4.6 (Continued)

\begin{tabular}{|c|c|c|c|}
\hline Country & Element & Strengths & Challenges \\
\hline & Finance & & $\begin{array}{l}\text { No clear budget for } M \& E \text { and } \\
\text { shortage of resources for } \\
\text { evaluations }\end{array}$ \\
\hline & $\begin{array}{l}\text { Follow-up } \\
\text { and use }\end{array}$ & & Limited use of evaluation findings \\
\hline & Data & & $\begin{array}{l}\text { UBOS statistics quality good and } \\
\text { reliable }\end{array}$ \\
\hline & & & $\begin{array}{l}\text { Lot of admin data not credible } \\
\text { leading to conflicting data }\end{array}$ \\
\hline & Timeliness & & $\begin{array}{l}\text { UBOS statistics often comes } \\
\text { very late }\end{array}$ \\
\hline \multirow[t]{13}{*}{$\begin{array}{l}\text { South } \\
\text { Africa }\end{array}$} & Leadership & $\begin{array}{l}\text { Much better when M\&E } \\
\text { function located in } \\
\text { director general's office } \\
\text { M\&E led from the } \\
\text { presidency }\end{array}$ & \\
\hline & Culture & $\begin{array}{l}\text { Able to provide evidence of } \\
\text { kind of work being done }\end{array}$ & \\
\hline & System & $\begin{array}{l}\text { Because led by } \\
\text { government, more } \\
\text { willing to use results }\end{array}$ & Evaluations not fully independent \\
\hline & & Degree of standardisation & $\begin{array}{l}\text { Many frameworks not under one } \\
\text { umbrella }\end{array}$ \\
\hline & & $\begin{array}{l}\text { Evaluation become very } \\
\text { strong. NES working very } \\
\text { well. National evaluation } \\
\text { policy framework, } \\
\text { capacity building, and } \\
\text { guidelines exist }\end{array}$ & $\begin{array}{l}\text { Non-regulation is a weakness } \\
\text { because some departments don't } \\
\text { do evaluation. Evaluation after } \\
\text { every programme should be } \\
\text { compulsory }\end{array}$ \\
\hline & & $\begin{array}{l}\text { Strength of what is done } \\
\text { huge }\end{array}$ & $\begin{array}{l}\text { Lack of good monitoring systems. } \\
\text { Monitoring information not } \\
\text { necessarily providing good } \\
\text { performance reports against } \\
\text { Annual Performance Plan }\end{array}$ \\
\hline & & $\begin{array}{l}\text { Evaluation policy and } \\
\text { guidelines }\end{array}$ & $\begin{array}{l}\text { Don't work as well as they should } \\
\text { with provinces on planning and } \\
\text { M\&E }\end{array}$ \\
\hline & & & $\begin{array}{l}\text { Evaluations done by departments } \\
\text { separately from planning }\end{array}$ \\
\hline & HR & $\begin{array}{l}\text { Fully fledged evaluation } \\
\text { team in DPME }\end{array}$ & $\begin{array}{l}\text { Limited capacity of both policy } \\
\text { makers and technical staff in } \\
\text { the evaluation sector, with few } \\
\text { service providers in the sector }\end{array}$ \\
\hline & & & $\begin{array}{l}\text { In government there are no } \\
\text { evaluation people }\end{array}$ \\
\hline & & & $\begin{array}{l}\text { While called M\&E, most of us are } \\
\text { not strong in evaluations }\end{array}$ \\
\hline & & & $\begin{array}{l}\text { Need to develop more black } \\
\text { evaluators }\end{array}$ \\
\hline & & & $\begin{array}{l}\text { Turnover, with new managers } \\
\text { always starting something new }\end{array}$ \\
\hline
\end{tabular}




\begin{tabular}{clll}
\hline Country & Element & Strengths & Challenges \\
\hline Funding & & $\begin{array}{c}\text { Programme funding needs to } \\
\text { include funds for evaluation } \\
\text { Evaluation is costly }\end{array}$ \\
& & Are managers using reports? \\
Follow-up & Evaluations done of key & programmes so that & Usage of evaluation information \\
and use & practices improve & sometimes doesn't happen as \\
& & you would want it to \\
& & Evaluation takes time \\
\hline
\end{tabular}

Source: Interview respondents, baseline study.

and resulting in instability (especially South Africa). Around 50\% of managers reported lack of ownership of $M \& E$ with $M \& E$ regarded as the job of the $M \& E$ unit, not of all managers; lack of respect for evidence-based decision making; and with around 40\% saying senior managers are not championing M\&E. The dominant culture is one of compliance and punitive, with a fear of making mistakes and so inhibiting learning.

In terms of systemic factors, we see five main areas:

- Weaknesses in the public service with limited capacity to undertake evaluations (55\% of respondents), but a $25 \%-33 \%$ proportion saying that managers do not have the skills to understand and use evaluation recommendations, or management skills to use results. This is perpetuated by limited resources for $\mathrm{M} \& \mathrm{E}$, and in particular evaluation (70\% of respondents) as well as poor salaries and poorly motivated public servants.

- $\quad$ Systems challenges due to silos leading to separation of M\&E from planning and budget (all three countries); duplication in reporting requirements and reporting fatigue (mentioned for SA); weak manual data systems in some locations, especially in rural areas, a contributor to poor quality administrative data (all).

- Poor implementation, either due to inadequate quality of evaluations $50 \%$ of respondents felt conclusions are often not helpful), or weaknesses in following up evaluations, either because there is no improvement plan system (e.g. Benin and Uganda) or because improvement plans are not followed up adequately, as in South Africa (DPME, 2018).

- Managers not seeing their role as anticipating the evidence needs of ministers or senior managers, and being required to provide evidence at the last minute, meaning decisions are taken without effective diagnosis because of time pressure.

- Donors sometimes operating parallel systems (all).

- Involvement of civil society weak in holding government to account, with civil society linkages weakest in South Africa. 


\section{Conclusions}

Table 4.7 summarises the overall picture against the contextual elements identified at the beginning of this chapter, and the pattern for the three countries is surprisingly similar. What emerges is a mixed picture where, in these countries, the location of the driver of $M \& E$ gives it some authority. There appears to be significant demand for $M \& E$ evidence from ministers and senior managers and in around half of cases, respondents indicated there was a positive environment

Table 4.7 Summary of features of the context in Uganda, Benin and South Africa

\begin{tabular}{|c|c|}
\hline Dimension of context & Summary \\
\hline $\begin{array}{l}1 \text { Macro-context } \\
\text { (external) }\end{array}$ & $\begin{array}{l}\text { In all three cases, there are powerful centre of government } \\
\text { M\&E roles. In some, these are a consequence of crises } \\
\text { and transitions, which have also affected leadership. Role } \\
\text { of donors is powerful in Uganda and Benin }\end{array}$ \\
\hline \multirow{4}{*}{$\begin{array}{l}2 \text { Intra- and inter- } \\
\text { institutional linkages } \\
\text { (external) }\end{array}$} & $\begin{array}{l}\text { Coordination is weak across government generally, stronger } \\
\text { in M\&E space }\end{array}$ \\
\hline & $\begin{array}{l}\text { Some transparency, and reports are shared. Much more } \\
\text { work on communication needed }\end{array}$ \\
\hline & Consultation with non-state actors weak in South Africa \\
\hline & $\begin{array}{l}\text { Performance information (e.g. evaluation reports) is used } \\
\text { for wider accountability }\end{array}$ \\
\hline \multirow[t]{5}{*}{3 Culture (internal) } & High demand from ministers for evidence \\
\hline & $\begin{array}{l}\text { Half of managers are supportive of using evidence, but } \\
\text { around half do not use problems for learning }\end{array}$ \\
\hline & Historical evidence used more than real time \\
\hline & Cultures still largely compliance driven \\
\hline & $\begin{array}{l}\text { Challenges with management attitudes, e.g. hierarchy that } \\
\text { affects ability to take risks and learn }\end{array}$ \\
\hline $\begin{array}{l}4 \text { Organisational capacity } \\
\text { (internal) }\end{array}$ & $\begin{array}{l}\text { High-level political leadership in M\&E. In a significant } \\
\text { proportion of ministries the person responsible for } \\
\text { M\&E is high level. M\&E units - the central unit and } \\
\text { ministry units - are of significant size. There are limits to } \\
\text { management's capacity and will to use evidence }\end{array}$ \\
\hline \multirow[t]{5}{*}{$\begin{array}{l}5 \text { Management and } \\
\text { processes (internal) }\end{array}$} & $\begin{array}{l}\text { All three have national development plans and monitor } \\
\text { these. Benin is weak in linking performance agreements } \\
\text { to the national and ministry plans }\end{array}$ \\
\hline & $\begin{array}{l}\text { Monitoring is done but largely for compliance and there is } \\
\text { reporting fatigue }\end{array}$ \\
\hline & All three have national evaluation systems \\
\hline & $\begin{array}{l}\text { Around } 50 \% \text { of managers use evidence, with }>60 \% \\
\text { instrumental and conceptual use }\end{array}$ \\
\hline & $\begin{array}{l}\text { Basic communications occur, but not much wider media, } \\
\text { which would broaden access }\end{array}$ \\
\hline \multirow{3}{*}{$\begin{array}{l}6 \text { Other resources } \\
\text { (internal) }\end{array}$} & Budgets for evaluation and research are limited \\
\hline & $\begin{array}{l}\text { Limited knowledge infrastructure, e.g. evaluation } \\
\text { repositories }\end{array}$ \\
\hline & $\begin{array}{l}\text { Managers felt information system provides information } \\
\text { needed }\end{array}$ \\
\hline
\end{tabular}


for evidence use; and 60\%-70\% reported that evidence from evaluations is used, with instrumental, conceptual, process and symbolic use emerging. This is fairly consistent across the three countries.

However, half of respondents indicated there was a negative attitude to $\mathrm{M} \& \mathrm{E}$, with findings concealed, senior management not championing honesty about performance, little respect for evidence-based decision making, and managers fearing to admit mistakes. The hierarchy impedes learning and M\&E is not seen as very influential.

This creates a mixed environment for learning, with a compliance culture still dominant. Some ministries are performing better, have stronger M\&E systems, and use evidence, while others are very weak.

A high percentage of managers do not support M\&E for learning because they lack the expertise and tools to deal with the M\&E system, or because M\&E may weaken their position and power in the organisation. Around 40\% indicated the hierarchy made it difficult to discuss performance, and they feared admitting problems. This suggests it is autocratic management creating a punitive culture that impedes learning. In around a quarter of cases it appears that the skills to understand and use evaluation recommendations are a problem, and where culture is favourable, this may be easier to address through different capacity-strengthening interventions.

Compliance is clearly the dominant culture of the public service, and yet around half the managers believe that learning does happen.This is likely to ebb and flow, depending on the attitude and culture of top management. Autocratic managers are likely to promote compliance behaviour, as is a dominance of the auditor-general, with managers aiming for compliance rather than innovation. Some respondents indicated that evaluation is seen as a witch-hunt. Evaluation needs to be more widely understood and seen to be within a set of tools for adaptive management.

\section{An action perspective}

These three countries have a good base on which to build national evaluation systems that produce results to use for improvements. How can this be built on to reduce negative compliance behaviour? Several methods are suggested:

- Continuing to provide the message that evaluation is not intended to be punitive but for continuous improvement. This requires sustained approaches, and can be jeopardised by transitions.

- $\quad$ Providing incentives for using evaluations for learning, for example symbolic behaviour by politicians praising senior managers who learn and improve; focusing on Ministries of Finance requiring evidence to inform funding of new programmes; planning and performance management systems requiring managers to implement recommended changes; and donors using a learning mindset. 
- Focusing on champions able to take evaluations forward in a learning manner.

- Building coalitions across departments to support M\&E as part of adaptive management.

- $\quad$ Providing a range of evidence in a responsive way, so building up the perceived value of $M \& E$, for example by having rapid methods as well as traditional evaluations.

- Sharing examples of good practice.

- $\quad$ Training senior managers in evidence, as has started in the three countries.

- $\quad$ Recognising that autocratic management has negative side effects and recruiting senior managers with more empowering management styles.

- Opening the evaluation process so that Parliament, the media and the public can bring pressure for improvements but handled carefully as it can increase fear of exposure from evaluation.

As Mayne (2010) says:

Developing an evaluative culture . . . requires deliberate efforts by the organization and especially its senior managers to encourage, implement, and support such a culture. It needs to be clear to managers and staff that results information and evidence are valued and expected to be a regular part of planning, budgeting, implementation, and review.

(Mayne, 2010, p. 22)

This chapter has sought to provide a picture of the context to evidence use in three of the five countries covered in the book. Overall, establishment of effective $M \& E$ systems is a component of creating a performance culture but is not enough. We see examples of systems, and 50\% of managers indicate that evidence is valued and used. Using evidence must become part of how organisations work. But developing such a culture is not a short-term project. The evaluation of South Africa's NES concluded that establishing the NES is a 20-year project (DPME, 2018, p. xi), and these three countries have been implementing NES for 8-12 years - the reality is that developing M\&E systems and culture that promote learning and use is an ongoing project.

\section{Notes}

1 National departments/ministries that formed part of the survey are President/Prime Minister's Office/Agriculture/Education/Finance/Health/Social Development/Planning and Economic Development/Labour, Public Administration and Social Affairs/ Higher Education and Scientific Research/Secondary Education, Technical and Professional Training/Bureau of Evaluation of Public Policies and Analysis of Governmental Action of General Secretary of Presidency (BEPPAAG/SG-PR).

2 Uganda puts all the performance reports on the budget transparency initiative website (www.budget.go.ug), and South Africa also has online budget information for national and provincial government (www.treasury.gov.za), as well as a municipal budget website (https://municipaldata.treasury.gov.za/). 
3 http://s.mo.ibrahim.foundation/u/2018/10/26211727/2018-IIAG-country-scorecards. zip?_ga=2.132075023. 1604460325.1560161521-1633358436.1560161521

4 The most recent Annual Performance Report for government is September 2015, and for Local Government Performance Assessment is June 2018.

5 This department has done 22 evaluations (Dirk Troskie, personal communication).

6 For example, the African Evaluation Database (AFRED) of evaluations developed by CLEAR AA and CREST indicates 521 evaluations that at least partly cover Tanzania. In recently conducted training of senior Tanzanian officials, it was found that they were unaware that this resource exists. Similarly, in preparing an evidence map for Uganda, White (2019) found over 500 evaluations in Uganda.

7 A simple table has been developed using evaluation findings, recommendations, degree of implementation of the recommendations/improvement plans and the implications for the budget process.

8 The report is available at www.twendembele.org/wp-content/uploads/2018/11/TwendeMbele-Report-Final-Nov-2018_Budgets-Planning2.pdf, accessed 17 August 2019.

\section{References}

Cameron, K.S. and Quinn, R.E. 1999. Diagnosing and changing organizational culture. Reading: Addison-Wesley.

DPME. 2014. Impact and implementation evaluation of government coordination systems: Final Report: Policy Summary, Executive Summary and Short Report (Evaluation Report). Department of Performance Monitoring and Evaluation.

DPME. 2018. Report on the evaluation of the national evaluation system: Summary report (Evaluation Summary Report). Department of Planning, Monitoring and Evaluation, Pretoria.

Goldman, I., Byamugisha, A., Gounou, A., Smith, L.R., Ntakumba, S., Lubanga, T., Sossou, D. and Rot-Munstermann, K. 2018. The emergence of government evaluation systems in Africa: The case of Benin, Uganda and South Africa. African Evaluation Journal, 6, 11. https://doi.org/10.4102/aej.v6i1.253

Gregory, R. 2006. Theoretical faith and practical works: De-autonomizing and joining-up in the New Zealand state sector, in Christensen,T. and Lægreid, P. (Eds), Autonomy and regulation: Coping with agencies in the modern state. London: Edward Elgar, pp. 137-161.

Mayne, J. 2010. Building an evaluative culture: The key to effective evaluation and results management. The Canadian Journal of Program Evaluation, 24, 1-30.

New Zealand State Services Commission. 2008. Factors for successful coordination: Helping state agencies coordinate effectively, available at: http://www.ssc.govt.nz/sites/all/files/Factors\%20 spreadsheet.pdf, accessed 23/05/2013

Paine Cronin, G. and Sadan, M. 2015. Use of evidence in policy making in South Africa: An exploratory study of attitudes of senior government officials. African Evaluation Journal, 3. https://doi.org/10.4102/aej.v3i1.145

Phillips, S., Goldman, I., Gasa, N., Akhalwaya, I. and Leon, B. 2014. A focus on M\&E of results: An example from the Presidency, South Africa. Journal of Development Effectiveness, 6, 392-406. https://doi.org/10.1080/19439342.2014.966453

Porter, S. and Goldman, I. 2013. A growing demand for monitoring and evaluation in Africa. African Evaluation Journal, 1, 9. https://doi.org/10.4102/aej.v1i1.25

Rogger, D. and Somani, R. 2018. Hierarchy and information. Policy Research Working Paper 8644, World Bank, Washington, available at http://documents.worldbank.org/ curated/en/474061541787560854/pdf/WPS8644.pdf, accessed 23/03/2020.

Umlaw, F. and Chitepo, N. 2015. State and use of monitoring and evaluation systems in national and provincial departments. African Evaluation Journal,3.https://doi.org/10.4102/ aej.v3i1.134 


\section{Ian Goldman et al.}

Uneke, C.J., Ezeoha, A.E., Ndukwe, C.D., Oyibo, P.G., Onwe, F., Igbinedion, E.B. and Chukwu, P.N. 2011. Individual and organisational capacity for evidence use in policy making in Nigeria:An exploratory study of the perceptions of Nigeria health policy makers. Evidence \& Policy, 7, 251-276. https://doi.org/10.1332/174426411X591744

Weyrauch,V., Echt, L. and Suliman, S. n.d. Going beyond. Context Matters, 73.

Weyrauch, V., Echt, L. and Suliman, S. 2016. Knowledge into policy: Going beyond context matters-framework.

White, H. 2019. The twenty-first century experimenting society: the four waves of the evidence revolution. Palgrave Communications, 5, 47, https://doi.org/10.1057/s41599-0190253-6 